\title{
OCCURRENCE OF VibRation UNDER Changing SPINDLE SPEED DURING CNC MiLLING
}

\author{
Štefánia Salokyová \\ Technical University of Košice, Faculty of Manufacturing Technologies, \\ Department of Manufacturing Processes Operation, Bayerova 1, 08001 Prešov, Slovakia \\ e-mail: stefania.salokyova@tuke.sk
}

\begin{abstract}
Vibrations are an inseparable effect occurring during the operation of every technical device. Especially because of this the measurement was focused on examining vibrations on the milling cutter. During the measurement the rotation speed of the milling cutter was changing as well as the two types of milling tools, with which the examined material steel 1.1213 was process, with material removal of $2.7 \mathrm{~mm}$ set in advance. The waveforms of technological head vibration acceleration amplitude and their frequency spectra are evaluated. Based on measured values, two graphical dependencies were created and subsequently compared with the allowed vibration value on class of the milling machines. New knowledge and conclusions are drawn based on measured results.
\end{abstract}

\section{Introduction}

Milling is an operation of splinter processing, during which a layer of material is removed from the processed material in the form of individual splinters by the means of a rotation tool - milling machine $[1,2]$. During milling operations, the milling machine is rotating around its axis and with its perimeter cutters gradually cut into the processed material, which is moving against the cutting head at the same time. Every cutter tooth gradually cuts away short splinters of various degrees of thickness from the processed material, so the processing is interrupted [3]. During the milling of the processed material, vibration occurs on the system machine - tool - processed material. During the milling, vibrations occur due to two reasons [4, 5, 6, and 7]. Firstly, because of the fact that during the milling the splinter is removed intermittently under various angles of the cutter [8]. These vibrations are caused by the operation of the tool and we view them as a common consequence of this type of processing. The second reason is the fact that the cutter teeth process a corrugated surface. Therefore it is desirable to place the processed material against the milling cutter in such a way that during the processing as many teeth would process it at the same time as possible.

\section{Conditions of the experiment}

Vibrations were observed on the cutter of a CNC milling machine Zayer $3000 \mathrm{BF}$. The vibrations are observed in the $\mathrm{X}$-axis, $\mathrm{Y}$-axis vibration values were negligible. The placement of the sensor is depicted in detail in Fig. 1. Four subsequent measurements were made split in 2 experiments. During the processing of the structural alloy steel 1.1213, the speed of the milling cutter was changing as well as two types of milling tools of a plate type R245080Q27-12M (Fig. 2) and a monolith type NR TiN 50x36 (Fig. 3). The technical parameters for plate milling cutters R245-080Q27-12M are listed in Table 1 and for monolith milling cutters NR TiN 50x36 in Table 2. Changing and constant technological and material parameters used during the experiments are listed in Table 3. 


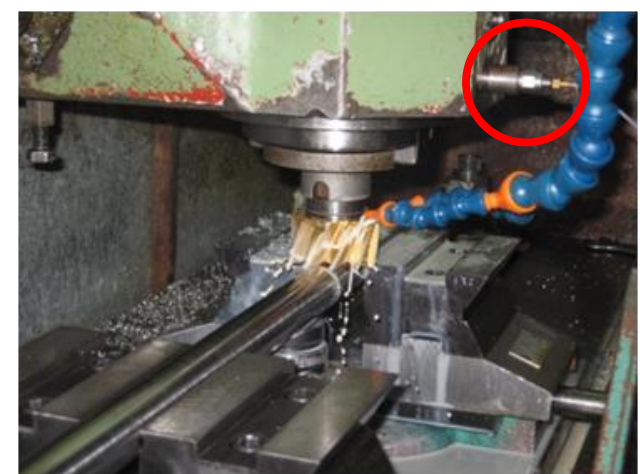

Source: Own

Fig. 1: Placement of the vibration sensor

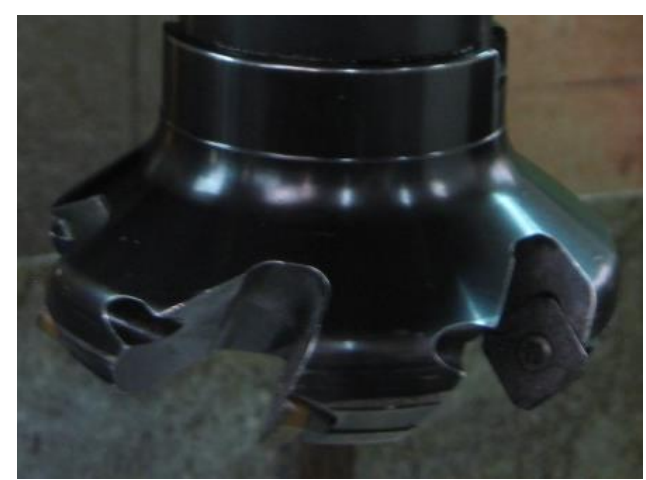

Source: Own

Fig. 2: Plate milling cutters R245080Q27-12M

Tab. 1: Technical parameters for plate milling cutters R245-080Q27-12M

\begin{tabular}{|c|c|c|c|c|}
\hline $\begin{array}{c}\text { connection } \\
\text { diameter }\end{array}$ & $\begin{array}{c}\text { cutting diameter face } \\
\text { contact }\end{array}$ & $\begin{array}{c}\text { maximum cutting } \\
\text { diameter }\end{array}$ & $\begin{array}{c}\text { maximum } \\
\text { overhang }\end{array}$ & $\begin{array}{c}\text { depth of cut } \\
\text { maximum }\end{array}$ \\
\hline $27 \mathrm{~mm}$ & $80 \mathrm{~mm}$ & $92.5 \mathrm{~mm}$ & $50 \mathrm{~mm}$ & $6 \mathrm{~mm}$ \\
\hline
\end{tabular}

Source: Own

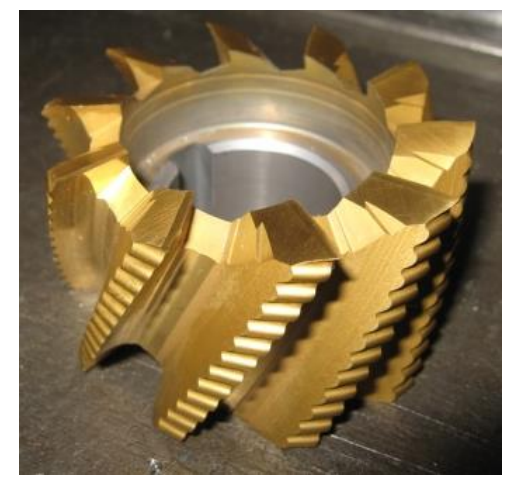

Source: Own

Fig. 3: Monolith milling cutters NR TiN 50x36

Tab. 2: The technical parameters for monolith milling cutters NR TiN $50 \times 36$

\begin{tabular}{|c|c|c|c|}
\hline helix angle & cutting diameter & the diameter of clamping element & length of cutters \\
\hline $27^{\circ}$ & $50 \mathrm{~mm}$ & $22 \mathrm{~mm}$ & $36 \mathrm{~mm}$ \\
\hline
\end{tabular}

Source: Own

Tab. 3: Conditions of the experiments

\begin{tabular}{|c|c|}
\hline \multicolumn{2}{|c|}{ Changing parameters } \\
\hline Speed of the milling cutter & Milling cutters \\
\hline $200 \mathrm{rpm}$ & plate milling cutters R245-080Q27-12M \\
\hline $250 \mathrm{rpm}$ & monolith milling cutters NR TiN 50x36 \\
\hline
\end{tabular}

\begin{tabular}{|c|c|c|}
\hline \multicolumn{3}{|c|}{ Constant parameters } \\
\hline Reduction of the material & Shift & Materials \\
\hline $2.7 \mathrm{~mm}$ & $150 \mathrm{~mm} / \mathrm{min}$ & steel 1.1213 \\
\hline
\end{tabular}

Source: Own 
The measured values on the vibration acceleration amplitude are collected from the 4514B62887 sensor made by the Brüel \& Kjaer company, which was attached on the spindle head by a magnet and processed by a digital converter $\mathrm{AD}(\mathrm{AI} \pm 5 \mathrm{~V}$ IEPE, sampling $25 \mathrm{kSps}$ ), through which the recorded data are stored in a PC (LENOVO) as a time log of the vibration acceleration signal $[9,10]$.

For the evaluation of the time signal the SignalExpress software was used, which is part of the programming and developmental environment LabVIEW of the National Instruments company. A ten-second steady course section was selected from the time recording and through Fourier transformation a frequency spectrum in the range $3.0-8.0 \mathrm{kHz}$ was created. The frequency spectrum covers were produced by using an algorithm filter with the help of the Microsoft Office Excel software [9, 10].

\section{$3 \quad$ Measured values}

The measured values for individual experiments and the two examined speeds of the spindle head (200 and $250 \mathrm{rpms}$ ) are depicted in the form of a vibration acceleration amplitude time lapse. An example of a vibration acceleration amplitude time lapse for spindle head speed 200 rpms for plate and monolith milling cutters is depicted in Fig. 4 and 5.

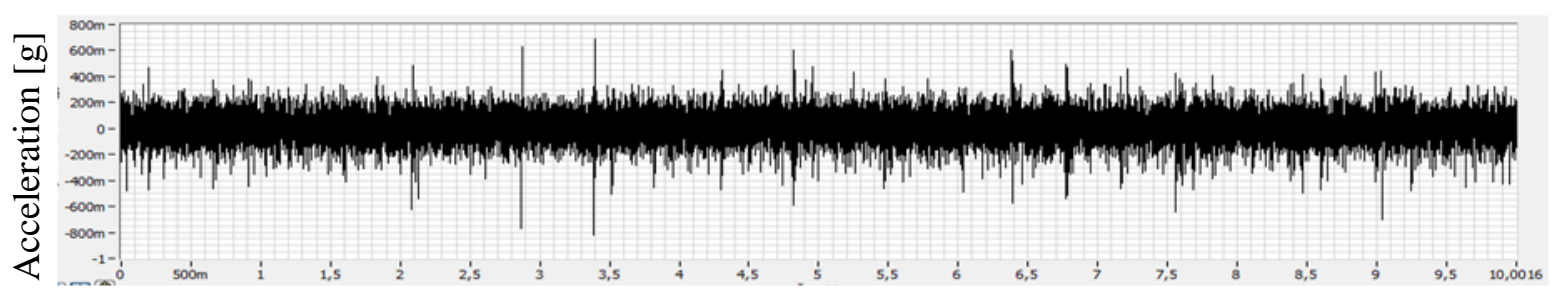

Time $[\mathrm{s}]$

Source: Own

Fig. 4: Vibration acceleration amplitude lapse dependent on time of the plate milling cutters with material removal of $2.7 \mathrm{~mm}$ and speed of $200 \mathrm{rpms}$

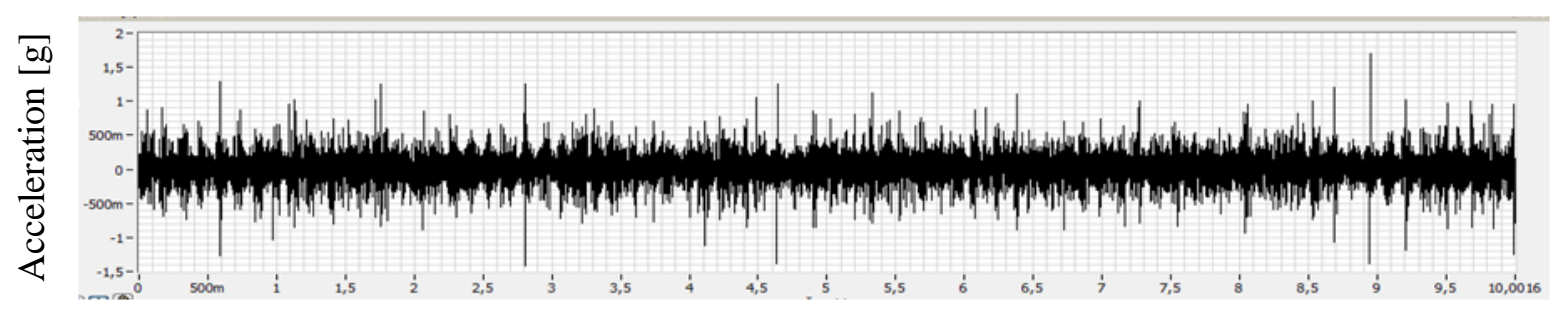

Time $[\mathrm{s}]$

Source: Own

Fig. 5: Vibration acceleration amplitude lapse dependent on time of the monolith milling cutters with material removal of $2.7 \mathrm{~mm}$ and speed of $200 \mathrm{rpms}$

\section{$4 \quad$ Evaluation of measured values}

The evaluation consists of creating vibration acceleration frequency ranges amplitude in the range of 3.0 to $8.0 \mathrm{kHz}$; below $3 \mathrm{kHz}$ vibration values were very small. Therefore the selected frequency range of 3.0 to $8.0 \mathrm{kHz}$ was examined. As an example, Fig. 6 depicts the lapse of vibration acceleration amplitude changes dependent on frequency for speeds of $200 \mathrm{rpms}$ with the use of plate milling cutters, and the frequency range cover is depicted in Fig 7. A similar graphic dependency on frequency for speeds of $200 \mathrm{rpms}$ with the use of monolith milling cutters is depicted in Fig. 8. The frequency range cover is depicted in Fig. 9. Graphic 
dependencies of the acceleration amplitude ad vibration frequency and frequency range cover are depicted in a similar way with speed of $200 \mathrm{rpms}$ for plate and monolith milling cutters.

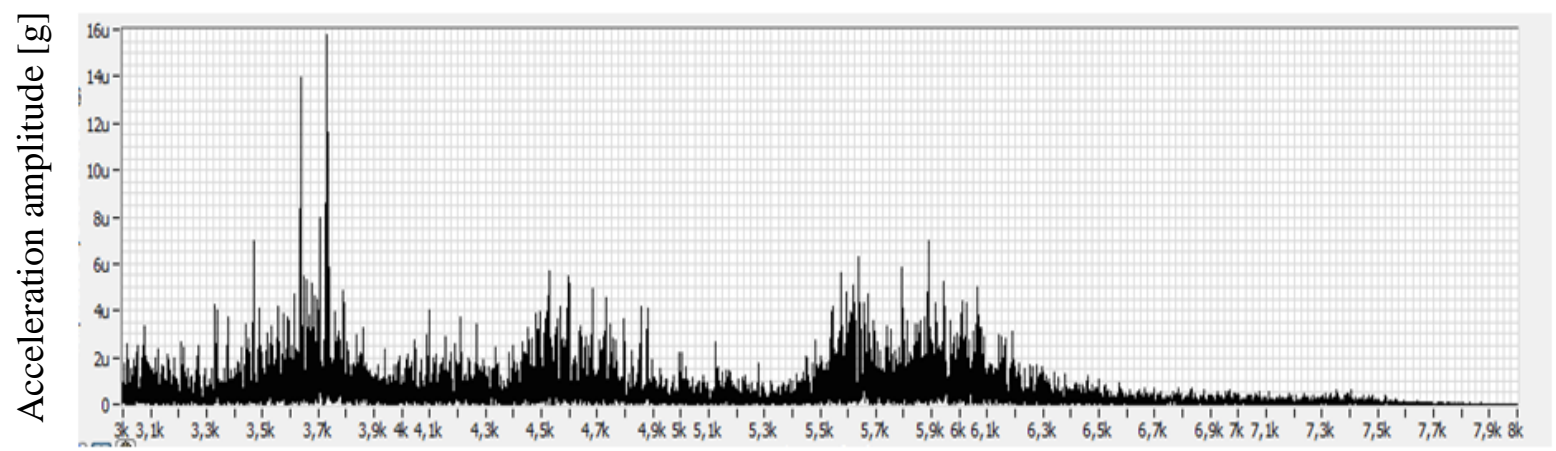

Frequency $[\mathrm{kHz}]$

Source: Own

Fig. 6: Graphic dependency of acceleration amplitude and vibration frequency with material removal of $2.7 \mathrm{~mm}$ and speed of $200 \mathrm{rpms}$ the spectrum $3.0-8.0 \mathrm{kHz}$

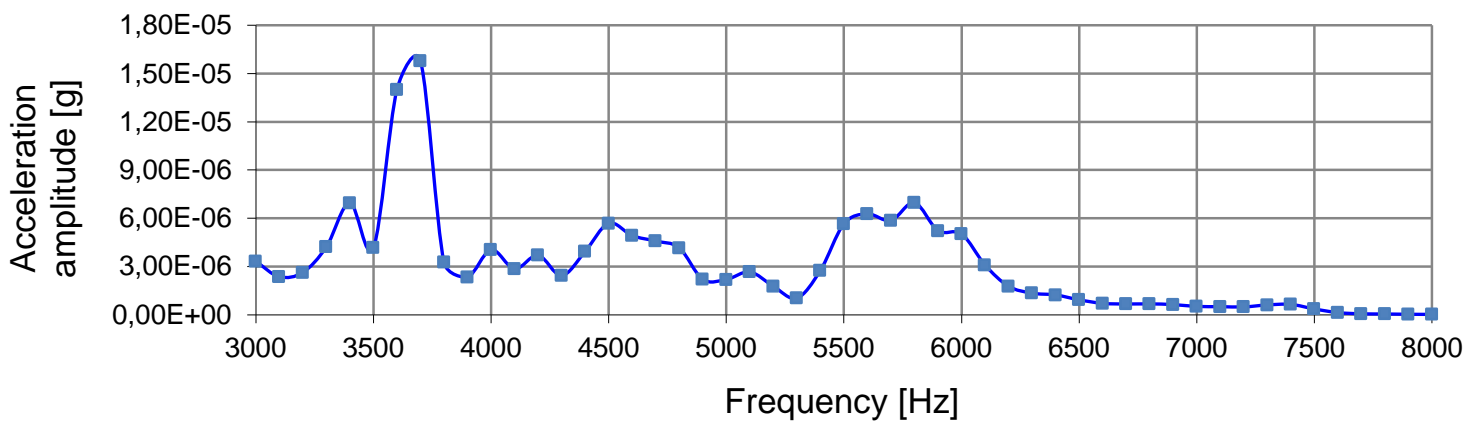

Source: Own

Fig. 7: Frequency range cover of plate milling cutters with material removal of $2.7 \mathrm{~mm}$ and speed of $200 \mathrm{rpms} 3.0-8.0 \mathrm{kHz}$

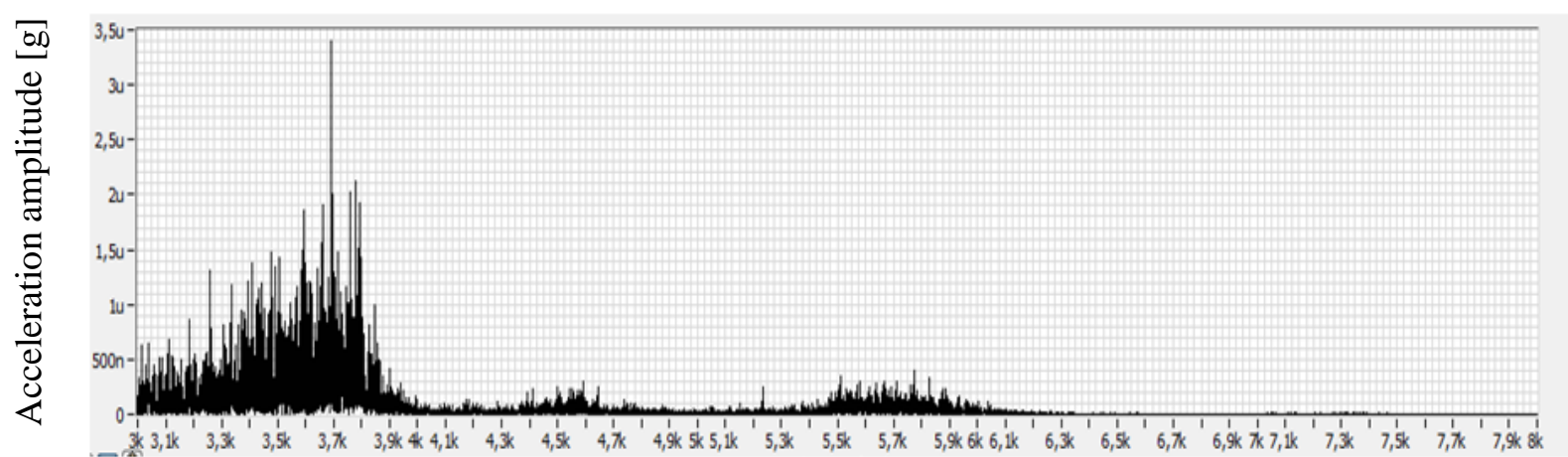

Frequency $[\mathrm{kHz}]$

Source: Own

Fig. 8: Graphic dependency of acceleration amplitude and vibration frequency of monolith milling cutters with material removal of $2.7 \mathrm{~mm}$ and speed of $200 \mathrm{rpms} 3.0-8.0 \mathrm{kHz}$ 


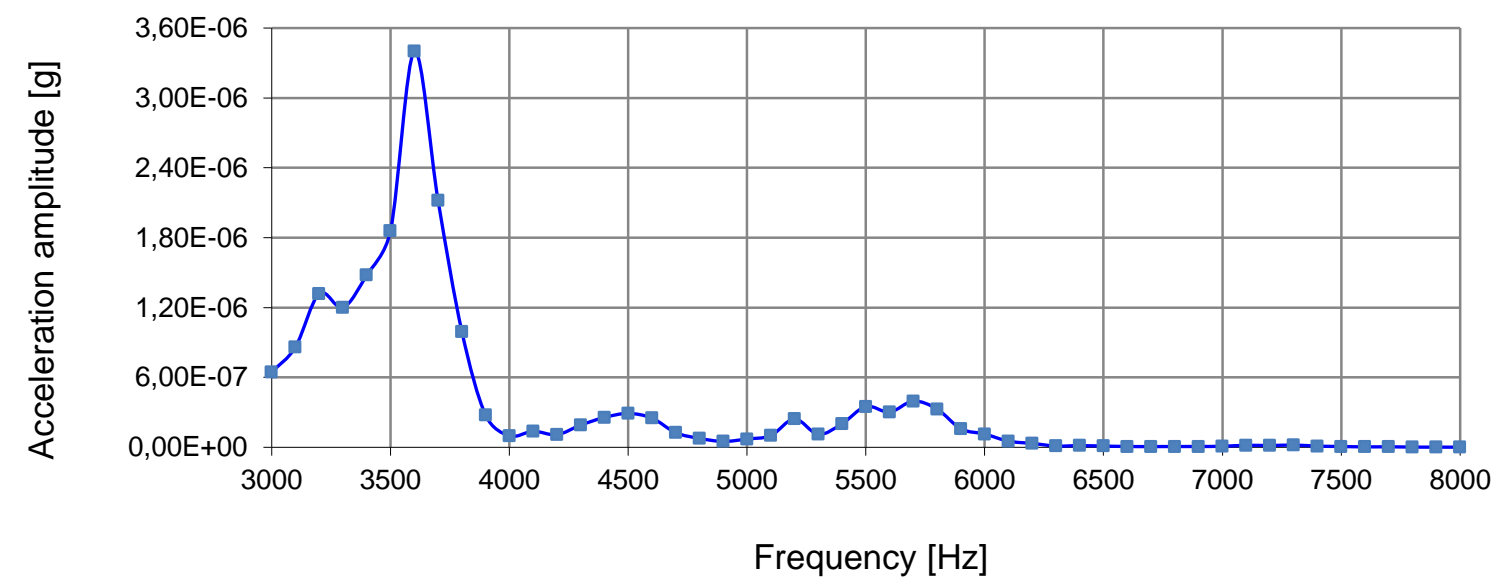

Source: Own

Fig. 9: Frequency range cover of monolith milling cutters with material removal $2.7 \mathrm{~mm}$ and speed of $200 \mathrm{rpms} 3.0-8.0 \mathrm{kHz}$

A comparison chart of vibration acceleration amplitude covers and frequency ranges individually for the two performed experiments are depicted in Figures 10 and 11.

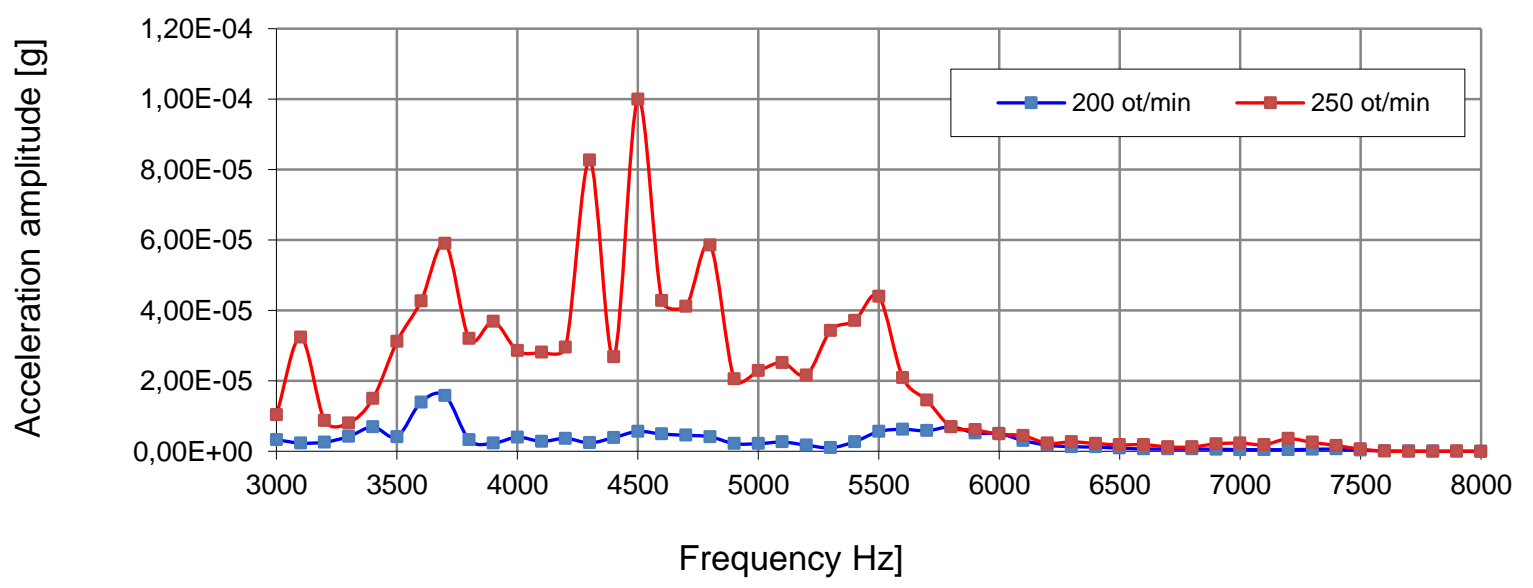

Source: Own

Fig. 10: Comparison chart of frequency spectrum covers of plate milling cutters with material removal $2.7 \mathrm{~mm}$ and speeds 200 and $250 \mathrm{rpms}$

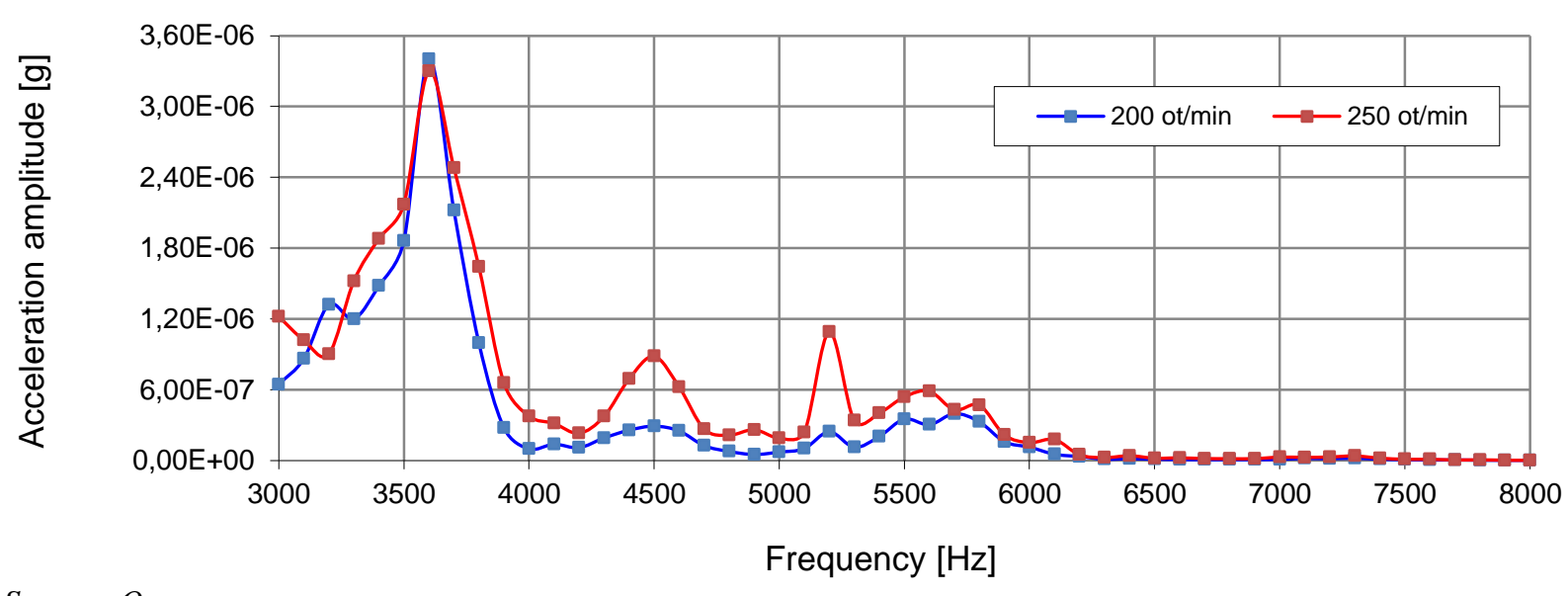

Source: Own

Fig. 11: Comparison chart of frequency spectrum covers of monolith milling cutters with material removal $2.7 \mathrm{~mm}$ and speeds 200 and $250 \mathrm{rpms}$ 
Comparison charts of vibration acceleration amplitudes covers and frequency ranges individually for spindle head speeds $200 \mathrm{rpms}$ and $250 \mathrm{rpms}$ are depicted in Figures 12 and 13.

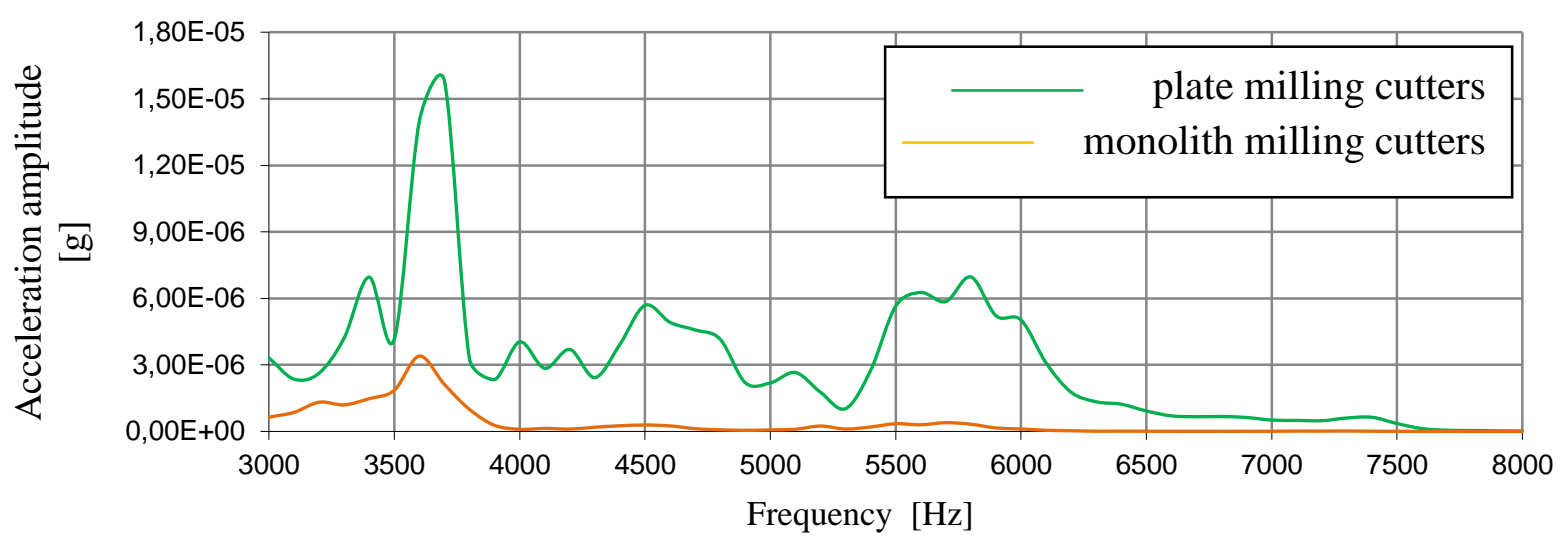

Source: Own

Fig. 12: Comparison chart of frequency ranges covers of plate and monolith milling cutters with material removal of $2.7 \mathrm{~mm}$ and speed of $200 \mathrm{rpms}$

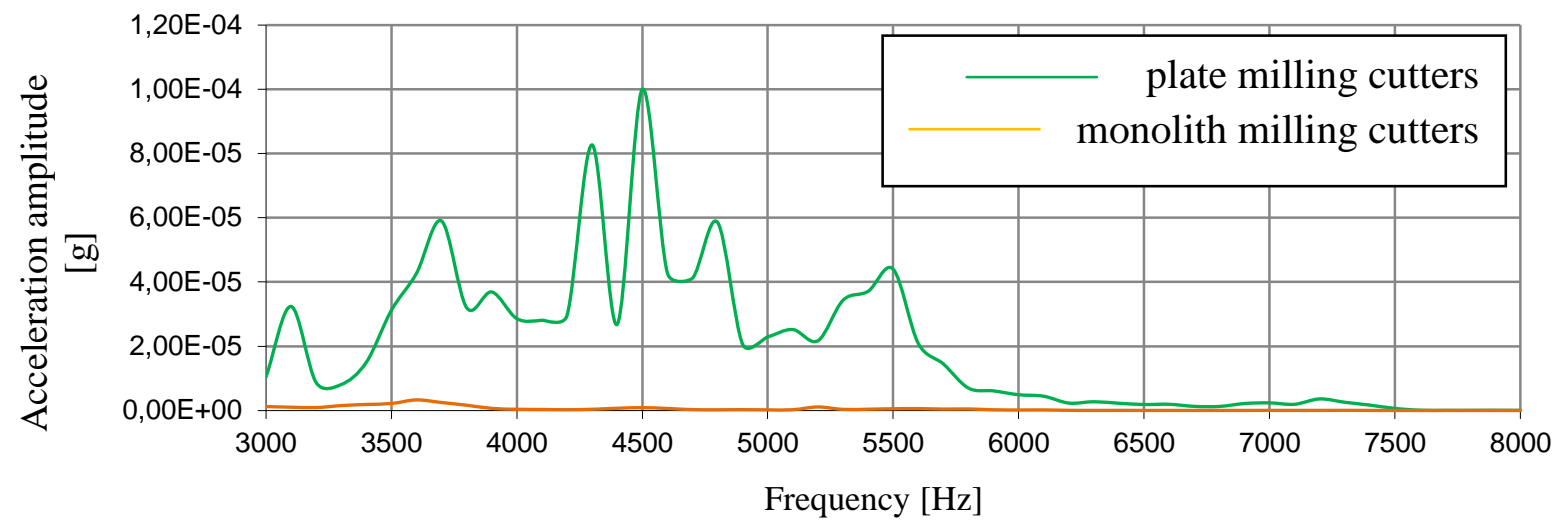

Source: Own

Fig. 13: Comparison chart of frequency ranges covers of plate and monolith milling cutters with material removal of $2.7 \mathrm{~mm}$ and speed of $250 \mathrm{rpms}$

Comparison chart of maximum vibration acceleration amplitude values individually for 2 examined motor speeds are depicted in Fig. 14.

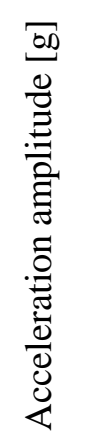

Source: $O w n$

Fig. 14: Comparison chart of maximum vibration acceleration amplitude values for both experiments 


\section{$5 \quad$ Evaluation of the experiments}

The text observes the effect of the spindle head rotations and the factor of removed thickness from the examined material on the creation of mechanical oscillation on the milling machine head during milling and the results are new knowledge and recommendations:

- for the two examined rotations of the spindle head of 200 and $250 \mathrm{rpm}$ with material removal of $2.7 \mathrm{~mm}$ (plate milling) the increased vibrations values in the observed range of $3.0-8.0 \mathrm{kHz}$ can be found in the frequency spectrum of $3.5-6.3 \mathrm{kHz}$

- the size of the vibrations acceleration amplitude with material removal of $2.7 \mathrm{~mm}$ (plate milling) in the comparison range reaches the highest value $1.58 \mathrm{E}-05 \mathrm{~g}$ for the frequency $3.6 \mathrm{kHz}$ and spindle head rotations of $200 \mathrm{rpm}$

- the size of the vibrations acceleration amplitude with material removal of $2.7 \mathrm{~mm}$ (plate milling) in the comparison range reaches the highest value $1.00 \mathrm{E}-04 \mathrm{~g}$ for the frequency $4.5 \mathrm{kHz}$ and spindle head rotations of $250 \mathrm{rpm}$

- for the two examined rotations of the spindle head of 200 and $250 \mathrm{rpm}$ with material removal of $2.7 \mathrm{~mm}$ (monolith milling) the increased vibrations values in the observed range of $3.0-8.0 \mathrm{kHz}$ can be found in the frequency spectrum of $3.0-3.9 \mathrm{kHz}$

- the size of the vibrations acceleration amplitude with material removal of $2.7 \mathrm{~mm}$ (monolith milling) in the comparison range reaches the highest value $3.40 \mathrm{E}-06 \mathrm{~g}$ for the frequency $3.3 \mathrm{kHz}$ and spindle head rotations of $200 \mathrm{rpm}$

- the size of the vibrations acceleration amplitude with material removal of $2.7 \mathrm{~mm}$ (monolith milling) in the comparison range reaches the highest value $3.30 \mathrm{E}-06 \mathrm{~g}$ for the frequency $4.5 \mathrm{kHz}$ and spindle head rotations of $250 \mathrm{rpm}$

- we can see from the frequency range cover (Fig. 10) with plate milling cutters and material removal of $2.7 \mathrm{~mm}$ that at the speed of $250 \mathrm{rpms}$ the maximum vibration amplitude value grew by $84.2 \%$ when compared to the speed of $200 \mathrm{rpms}$. Therefore it is recommended to process the material under these conditions at the speed of 200 rpms.

- we can see from the frequency range cover (Fig. 11) that during the monolith milling cutters processing with material removal of $2.7 \mathrm{~mm}$ the vibration amplitude values at speeds of 200 and $250 \mathrm{rpms}$ are approximately the same. The maximum value of vibration acceleration amplitude at the speed of $250 \mathrm{rpms}$ dropped in comparison to 200 rpms only minimally, specifically by $2.94 \%$.

- when processing at 200 to $250 \mathrm{rpms}$, it is recommended to use monolith milling cutters in comparison to the plate milling machine, because at $200 \mathrm{rpms}$ the difference of maximum value of vibration acceleration amplitude is $78.48 \%$. While using $250 \mathrm{rpms}$ the vibrations values dropped as much as $96.7 \%$.

\section{Conclusion}

The results and measured values of amplitudes and frequency spectrum point to the connection between input parameters and their values. Based on the analysis of the graphic relations of the vibrations acceleration amplitude and the frequencies we can state that with the increased speed of the rotations of the spindle head of the milling machine the values of the mechanical oscillation grew slightly. According to the maximum permissible limits for vibration milling machine Zayer $3000 \mathrm{BF} 3$ can be evaluated, long-term processing under given conditions does not produce such vibrations on the milling machine, which would 
reduce the durability and reliability of the machine, since the maximum value of vibration acceleration amplitude is $1.10^{-4} \mathrm{~g}$.

\section{Acknowledgements}

The research work was supported by the Project of the SF of the EU, Operational Programme Research and Development, Measure 2.2 Transfer of knowledge and technology from research and development into practice, project: Research and development of intelligent nonconventional actuators based on artificial muscles. ITMS code: 26220220103, projects VEGA 1/0409/13 and KEGA 027 TUKE - 4/2014.

\section{Literature}

[1] STAREK, L.: Kmitanie mechanických sústav. Bratislava: STU Bratislava, 2006. 316 p. ISBN 80-227-2491-2.

[2] KOCMAN, K.; PROKOP, J.: Technologie obrábění. Brno: Vysoké učení technické: Akademické nakladatelství CERM, 2005. 270 p. ISBN 80-214-3068-0.

[3] KOCMAN, K.: Frézovaní. Brno: Vysoké učení technické, 1999. 191 p. ISBN 80-2141425-1.

[4] KREHEL, R.: Vibračná diagnostika rotujúcich strojov. 2007. In: MM. Prưmyslové spektrum. No. 7, 8 (2007), p. 29. ISSN 1212-2572.

[5] SALOKYOVÁ, Š.: Evaluation of the vibration measurements during milling operations. 2014. In: Journal of Production Engineering. Vol. 17, no. 2 (2014), pp. 2125. ISSN 1821-4932.

[6] ŠOLTÉSOVÁ, S.; BARON, P.; SIMKULET, V.; MARCINKOVÁ, M.: Konkrétne metódy technickej diagnostiky určené pre sledovanie a monitorovanie stavu výrobných strojov a zariadení. 2013. In: Posterus. Vol. 6, No. 9 (2013), pp. 1-6. ISSN 1338-0087.

[7] PANDA, A.; PRISLUPČÁK, M.: Technologické faktory pôsobiace na obrábanie. In: Trendy a inovativne prístupy $v$ podnikových procesoch: 16. medzinárodná vedecká konferencia. 7. - 8.november 2013, Košice, 2013, pp. 1-7. ISBN 978-80-553-1548-5.

[8] BUGÁR, T.: Experimentálne metódy a technická diagnostika. Košice: TU, 2000. 49 p. ISBN 80-7099-539-4.

[9] SALOKYOVÁ, Š.: Analýza, modelovanie a simulácia vibrácií vo výrobných systémoch s technológiou vodného prúdu. Dissertation thesis. Prešov, 2012. 303 p.

[10] FABIAN, S.; KRENICKÝ, T.: Využitie vybraných vibrodiagnostických metód v monitoringu prevádzkových charakteristík strojových zariadení. 2010. In: Spravodaj ATD SR. No. 1, 2 (2010), pp. 32-34. ISSN 1337-8252.

Ing. Štefánia Salokyová, PhD. 


\section{VZNIK KMITÁNÍ VLIVEM MĚNÍCÍCH SE OTÁČEK VŘETENA PŘI FRÉZOVÁNÍ NA CNC}

\section{FRÉZCE}

Vibrace jsou průvodním jevem, který vzniká při provozu každého technického zařízení. Právě proto měření bylo zaměřeno na zkoumání vibrací na hlavě frézky. Během měření se měnily otáčky vřetena hlavy a dva druhy nástrojů frézy, při kterém se obdělával zkoumaný materiál ocel $1.1213 \mathrm{~s}$ předem nastaveným úběrem materiálu $2,7 \mathrm{~mm}$. Velikost vibrací je hodnocena dvěma základními parametry vibrací: amplituda zrychlení vibrací a frekvence vibrací. Z naměřených hodnot jsou vytvořeny grafické závislosti a následně jsou porovnány s dovolenou hodnotou vibrací zařazení frézky. Z naměřených výsledků jsou formulovány nové poznatky a závěry.

\section{DiE ENTSTEHUNG VON SCHWINGUNGEN DURCH WECHSELNDE SPINDELDREHZAHL FÜR DAS FRÄSEN AUF CNC-FRÄSMASCHINE}

Die Vibrationen sind ein untrennbare Begleiteffekt der entsteht bei den Betrieb von jeder Technischer Anlage. Deshalb wurde die Messung gerichtet auf Vibrationen Forschung auf dem Fräs-Kopf. Durch die Messung wurden die Drehungen auf dem Fräs-Kopf und auch zwei Arten von Werkzeugen verändert bei deren wurde der untersuchte Material Stehl 1.1213 bearbeitet mit vorher eingestellten Abtrag 2,7 mm. Von der gemessenen Werten sind die graphische Abhängigkeiten erstellt und anschließend sind sie vergleicht mit der erlaubten Wert von Vibrationen auf der Fräsmaschine. Aus den gemessenen Ergebnissen werden neue Feststellungen und Schlussfolgerungen formuliert.

\section{POWSTANIE OSCYLACJI Z POWODU ZMIENIAJĄCEJ SIĘ PRĘDKOŚCI OBROTOWEJ WRZECIONA DO FREZOWANIA NA FREZARCE CNC}

Drgania są towarzyszące zjawiska, wynikające z działania każdego urządzenia technicznego. Dlatego pomiar było zbadanie głowicy frezerskiej drgań. Podczas pomiarów zostały zmienione wrzeciona prędkość głowy i dwa rodzaje instrumentów młyna, w którym stal jest przepracowanych przez badanego 1.1213 góry ustalonym przez usunięcie materiału $2,7 \mathrm{~mm}$. Poziom drgań jest oceniany dwa podstawowe parametry wibracji: amplitudy przyspieszenia drgań o częstotliwości drgań i. Od zmierzone wartości są tworzone fabułę i są następnie porównywane $\mathrm{z}$ dopuszczalnym włączenia frezowania wibracje. $\mathrm{Z}$ wyników pomiarów sformułowano nowe ustalenia i wnioski. 